\title{
Economy and Farm Management in Malaysia: Principles and Practices
}

\section{Uqbah $\mid q b a l^{*}$}

\section{Life Planner, Kuala Lumpur, Malaysia}

Written by Mohd. Ghazali Mohayidin and Habibah Rohany, the writing of this book focuses on the systematic use of plantation management systems, especially on matters relating to storing records such as balance sheets, income statements to facilitate those involved with farm management to make an analysis of the profits or efficiency of farm management that during this is ignored. Each reader of this book is either a student at a higher education center, an agricultural officer, an expansion agent, an estate manager or a farmer who owns small plantations individually or in groups is expected to benefit from this book. This book contains examples taken from local plantation practices and practices to facilitate readers understand the economic theories and management concepts that play an important role in the success of the plantation system in Malaysia. There are five divisions in this book. Section 1 introduces the role and function of farm management in the plantation system as a whole. This section also explains several types of plantation systems practiced in Malaysia. In general, the agricultural production system in Malaysia has three different sectors, namely the smallholding sector, the plantation sector organized by the government and the estate sector. These three sectors each need different management systems.

Chapter 2 in Part 1 shows examples of the three sectors. Chapter 3 explains the need for research on plantation systems to enable the plant and animal systems to be repaired. This is important because technologies formed in a particular area may not be suitable for any other area. Chapter II describes the economic principles and cost concepts that are important in managing farms. Knowledge of economic principles can facilitate decision-making, especially in terms of minimizing costs or maximizing profits. The methods and techniques of planning discussed in Part III, which are business sector budgets, partial budgeting, farming planning and budgeting, and cash flow budgets are important methods or techniques in managing the estate efficiently. These tools are also useful to help managers or farmers decide on their daily business dealings.

Section IV introduces useful tools and concepts to control and monitor farm business activities. Financial statements such as balance sheets and income statements are among the most important tools. Methods and measurements that determine field performance such as ratio analysis, profitability analysis of all fields are also discussed in this Section. Farm records are described in Chapter 12. The functions of the plantation system are described in the last section of Part $\mathrm{V}$. This section contains chapters on capital and credit consumption, investment analysis, land management and management, labor and machinery management. The last chapter in this section discusses the rules of decision making in a state of risk and uncertainty. Management plays an important role in every aspect of everyday human life. A person acting as a farmer or farmer should manage his farm, while the trader should manage his business. Even as a human, he also needs to take care of his life and family matters. Every human being or group of people has their own goals, especially for those who are involved with an economic or social activity or others. The goal can be in formal form such as the goal of a large business company, or in informal form such as the goal of a social group. Nevertheless, in order to achieve these goals, those involved need to establish a program of planning, implementation and control of every activity to be undertaken. Malaysia as a developing country, despite having a booming industrial sector, still relies on the contribution of the agricultural sector to play an important role in the Gross National Product. If it is possible to improve the performance of a farmer, a farmer or someone managing a business agriculture entity, then the sector's contribution to the Gross National Product will be increased. The use of limited resources such as land, labor and capital in the best way to achieve a defined goal is one of the easiest forms of resource management. The process of management is a dynamic process, involving the responsibilities of the parties concerned to create and implement the plans and procedures of operation, preferences, guidance, encouragement and control over the persons involved in a business entity [1-5].

*Corresponding author: Uqbah Iqbal, Life Planner, Suite P4, Level 31, AIA Cap Square Tower, Jalan Munshi Abdullah, 50100 Golden Triangle, Kuala Lumpur, Malaysia

Accepted: January 14, 2019

Published online: January 16, 2019

Citation: Iqbal U (2019) Economy and Farm Management in Malaysia: Principles and Practices. Insights Anthropol 3(1):132133 


\section{References}

1. Thierauf RJ (1977) Management Principles \& Practices. John Wiley and Sons, New York.

2. Uyterhoeven HER, Ackerman RW, Rosenblum JW (1977) Strategy and Organisation. Richard D Irwin, Illinois.
3. Parkinson CN, Rustomji MK (1985) The Bible of Management. India Book House, Bombay.

4. Kinnear CT, Bernhardt KL (1983) Principles of Marketing. Scott, Foresman \& Co., USA.

5. James BG (1985) Business War Games. Penguin, England.

DOI: $10.36959 / 763 / 495$ 